\title{
ANALYSIS OF THE STUDENTS' PEDAGOGICAL CONTENT KNOWLEDGE AND CONTENT KNOWLEDGE IN MATHEMATICS LEARNING
}

\author{
Tina Sri Sumartini \\ Mathematics Education, Fakultas Ilmu Terapan dan Sains, Institut Pendidikan Indonesia \\ Jalan Terusan Pahlawan No. 32, Kab. Garut, Jawa Barat \\ Email: tinasrisumartini@institutpendidikan.ac.id
}

\begin{abstract}
:
Lack of Pedagogical Content Knowledge (PCK) and Content Knowledge (CK) of a teacher is a problem in the implementation of mathematics learning. There were various opinions about the correlation between PCK and CK of teacher's knowledge. Therefore, this study aims to analyze the correlation between them to the students of Mathematics Education as prospective mathematics teachers. The method used was a mix-method to determine the inferential correlation and to investigate deeply. The sampling technique used was purposive sampling by taking 33 students majoring in Mathematics education at Institut Pendidikan Indonesia. The results of the study indicated that there was a significant correlation between the students' PCK and CK as prospective teachers. PCK and CK were an integral part of teacher competence in teaching Mathematics. This study confirmed that the Mathematical beliefs of prospective teachers need serious attention. The implication in this study provided a statement about the importance of constructivism learning in the development of students' PCK and CK.
\end{abstract}

\begin{abstract}
Abstrak:
Kurangnya Pedagogical Content Knowledge (PCK) dan Content Knowledge (CK) seorang guru menjadi masalah dalam pelaksanaan pembelajaran matematika. Terjadi perbedaan pendapat tentang korelasi keduanya dalam struktur pengetahuan guru. Oleh karena itu dilakukan penelitian untuk menganalisis korelasi antara PCK dan CK pada mahasiswa jurusan Ppendidikan Matematika sebagai calon guru Matematika. Metode yang digunakan adalah mix-method untuk mengetahui korelasi secara inferensial dan menganalisis lebih dalam secara kualitatif. Teknik sampel yang digunakan yaitu puposive sampling dengan mengambil sampel sebanyak 33 mahasiswa jurusan pendidikan matematika di Institut Pendidikan Indonesia. Hasil dari penelitian menunjukkan bahwa terdapat korelasi yang signifikan antara PCK dengan CK mahasiswa sebagai calon guru. PCK dan CK merupakan satu kesatuan dari kompetensi guru dalam mengajar Matematika. Penelitian ini menegaskan bahwa keyakinan Matematis calon guru perlu mendapat perhatian yang serius. Implikasi dalam penelitian ini memberikan pernyataan tentang pentingnya pembelajaran kontruktivisme dalam pengembangan PCK dan CK mahasiswa.
\end{abstract}

Keywords:

Pedagogical Content Knowledge, Content Knowledge, Teacher Knowledge, Mathematics Learning

How to Cite: Sumartini, T., S. (2021). Analysis of the Students' Pedagogical Content Knowledge and Content Knowledge in Mathematics Learning. Lentera Pendidikan : Jurnal Ilmu Tarbiyah dan Keguruan, 24(1), 32-41. https://doi.org/10.24252/lp.2021v24n1i4. 


\section{INTRODUCTION}

Shulman (1986) argues that there is an imbalance between content knowledge and general pedagogical knowledge. This statement is obtained from research that studies how teachers understand the content and how that new understanding affects their teaching. It is the origin of the terms Content Knowledge (CK) and Pedagogical Content Knowledge (PCK). The deficiencies in these two aspects are considered as the missing paradigm in education. Shulman (1987) defines PCK as a special combination of content and pedagogical knowledge organized into two categories. The first category deals with teaching strategies and representations on how to regulate and adjust the subjects taught. The second category relates to knowledge about understanding the differences in students' characteristics. These two categories are unique professional skills of the teachers as a bridge that connects mathematical content and pedagogical knowledge.

There were five criticisms of Shulman's opinion stated by Depaepe, F., Verschaffel, L., \& Kelchtermans (2013) regarding PCK. First is the lack of theoretical and empirical foundation about PCK as a separate category in the teacher's knowledge base. The second is related to its static view of PCK as a type of factual knowledge obtained and applied independently from the classroom context. The third arises from the attention of researchers about the possibility of theoretically and empirically distinguishing PCK from content knowledge. Fourth is that Shulman made the PCK concept in only two categories. Fifth is the argument that PCK cannot be normative because it can vary according to culture.

One of the efforts to determine prospective mathematics teachers' professional and pedagogical abilities is by looking at the results of the Teacher Competency Test in the Neraca Pendidikan Daerah (NPD) of the Ministry of Education and Culture. It states that for West Java Province, the average value of teacher pedagogical competence is 54.36, and the professional competence of teachers is 60.95. Also, based on the result analysis of Şimşek \& Boz (2016), it was argued that prospective teachers still lack PCK and CK. Pedagogical Content Knowledge deals with the knowledge to understand the diversity of students' abilities, design and apply mathematics learning, evaluate learning outcomes, and develop students to actualize their various potentials. Meanwhile, content knowledge is related to the teacher's ability to master the learning material broadly and deeply, which allows him to guide students to obtain the expected competencies. Lack of this ability will result in unsuccessful mathematics learning. Teachers classified as young both in terms of age and teaching experience can understand the material well and understand the learning objectives. However, having PCK is not optimal, but also need mastery of teaching and understanding of students' needs (Margiyono \& Mampouw, 2011).

PCK and CK have an essential relationship owned by a teacher (Shulman, 1986). Both are teacher competencies that need to be prepared. In contrast to Even (1993), who argued that a teacher's CK and PCK were not yet known. Related to this opinion, what was highlighted in this study was the difference between PCK and CK based on teacher knowledge and the correlation between PCK and CK. The meta-analysis results proposed 
by Şimşek \& Boz (2016) revealed that most of the research had concentrated on determining the PCK that the prospective teachers and the most studied PCK component were knowledge about students and teaching strategies. It was also stated the need for further studies on teacher knowledge, including PCK and CK.

In mathematics learning, pedagogical competence plays a role in helping students understand the mathematical material. Ball et al. (2008) states that PCK consists of three characteristics, namely: Knowledge of Content and Student (KCS), Knowledge of Content and Teaching (KCT), and Knowledge of Curriculum (KC). KCS is related to the teacher's ability to anticipate the way students interact with concepts. Each student has a different way of responding to mathematical content. Therefore, the teacher needs to predict the way students think about the content being studied and know and analyze the misconceptions that occur in students in learning mathematics material. KCT relates to the teacher's ability to present mathematical content comprehensively. Presentation of material needs to be carefully prepared to determine the proper representation, method, and procedure so that the learning process is interwoven optimally. $\mathrm{KC}$ is related to the teacher's ability to understand the curriculum that is in force. Education is inseparable from government regulations in managing education. Therefore, teachers need to adjust the curriculum applied to the learning process that is being experienced. In this case, the development of students' abilities becomes important in educational goals.

Pedagogical Content Knowledge is a combination of knowledge with content, teaching, and curriculum (An, Kulm, \& Wu, 2004; Niess, 2005). A teacher delivers material and must know effective and innovative ways to develop students' abilities. The mathematical material will be interesting for students when the teacher can convey it appropriately. A teacher who masters mathematics material is not necessarily able to make students understand the content provided. Teachers classified as young both in terms of age or teaching experience can understand the material well and understand the learning objectives. However, there are still pedagogic abilities that are not optimal, namely mastery of teaching and understanding student needs (Margiyono \& Mampouw, 2011). Also, Kwong et al. (2007) provides illustrations of PCK, namely teacher's knowledge of mathematical structures and connections, provides a representation of concepts, provides cognitive demands from students' mathematical tasks, and understands student difficulties.

Ball, D.L., Thames, M.H., \& Phelps (2016) suggested the importance of PCK to represent the teacher's way of clarifying the meaning of mathematics and guiding students' thinking. McCray \& Chen (2012) suggested that PCK owned by teachers is needed for effective mathematics teaching. Therefore, the development of PCK needs to be consistently trained in the development of teacher education. In this case, students majoring in mathematics education become the right subjects in developing PCK. When they become teachers, they will be able to develop the potential possessed by students.

Content Knowledge (CK) is an important part of teacher knowledge (Dunekacke, Jenßen, \& Blömeke, 2015). CK includes a basic understanding and principle of a 
concept. Prospective teachers must understand and be able to explain concepts to students appropriately. Shulman (1986) shows that the teacher's understanding of subject matter must include not only knowing "that" but also knowing "why." Prospective teachers must understand the concept of quadratic functions in various representations such as illustrations, examples, and explanations. They also should be able to interpret and form inter-connections concepts in everyday life. By using different terms, prospective teachers can give a meaningful impression in mathematics learning. The teacher's knowledge of mathematics material is important to be seen in this study.

Content Knowledge represents the teacher's understanding of the material being taught (Kleickmann, Richter, \& Kunter, 2015). CK's emphasis lies in a teacher's deep understanding of the subject matter. The teacher not only knows that the roots of the quadratic equation $y=x^{2}+5 x+6$ are 2 and 3 but the teacher needs to give reasons for why.

\section{RESEARCH METHOD}

The research method used in this study is the mix-method method. Quantitative methods are used to see the correlation between PCK and CK inferentially. At the same time, the qualitative method is used to analyze PCK and CK students. The dominant qualitative method is used to assess the PCK of prospective teachers (Şimşek \& Boz, 2016). The instruments used were written tests and observation sheets. The written test uses an essay on the quadratic function of 5 questions to measure $\mathrm{CK}$ and eight questions to measure PCK. The instrument has been validated by three validators who are experts in the field of mathematics education. Data processing was carried out quantitatively using statistics to determine the correlation between CK and PCK. Furthermore, qualitative observations were made to students' answers from the tests given to analyze how the students' CK and PCK were.

The population in this study were all students majoring in mathematics education at the Institut Pendidikan Indonesia (IPI) Garut. The sample used was the second-year students of the Department of Mathematics in IPI Garut by taking 33 students for quantitative research and three students for qualitative research.

\section{RESULTS AND DISCUSSION}

Analysis of student work results is carried out quantitatively and qualitatively as follows:

The results of the descriptive analysis were obtained as follows:

Table 1. Descriptive Statistics

\begin{tabular}{llll}
\hline & Mean & Std. Deviation & N \\
\hline CK & 1,6970 & 0,89039 & 33 \\
\hline PCK & 1,5114 & 0,7149 & 33 \\
\hline
\end{tabular}

Based on Table 1, the average CK was 1.6970, and the average PCK was 0.7149 . The correlation between CK and PCK can be seen in the following table: 
Table 2. Correlations

\begin{tabular}{llll}
\hline & & CK & PCK \\
\hline CK & Pearson Correlation & 1 & 0,557 \\
\cline { 2 - 4 } & Sig. (2-tailed) & & 0,001 \\
\cline { 2 - 4 } & $\mathrm{N}$ & 33 & 33 \\
\hline \multirow{3}{*}{ PCK } & Pearson Correlation & 0,557 & 1 \\
\cline { 2 - 4 } & Sig. (2-tailed) & 0,001 & \\
\cline { 2 - 4 } & $\mathrm{N}$ & 33 & 33 \\
\hline
\end{tabular}

Based on Table 2 obtained sig value $>0.05$, it can be concluded that there is a correlation between PCK and CK.

Based on the analysis of student answers, there is uniformity regarding misconceptions made by students, including the following questions:

\section{Case 1}

Given the problem to students, namely: "How to explain the concept of function to be understood by students?" From these questions, students are expected to explain the concept of a function by starting to provide contextual problems so that students can observe the problem as an introduction to understanding the concept of function with teacher guidance.

Most students answer almost the same answer by explaining the function material directly and explaining the concept using examples and non-examples. This result indicates that the presentation of the problem at the beginning of learning is still rarely done even though students need to be given meaningful learning through mathematical problems. One of the students' answers can be seen in the following picture:

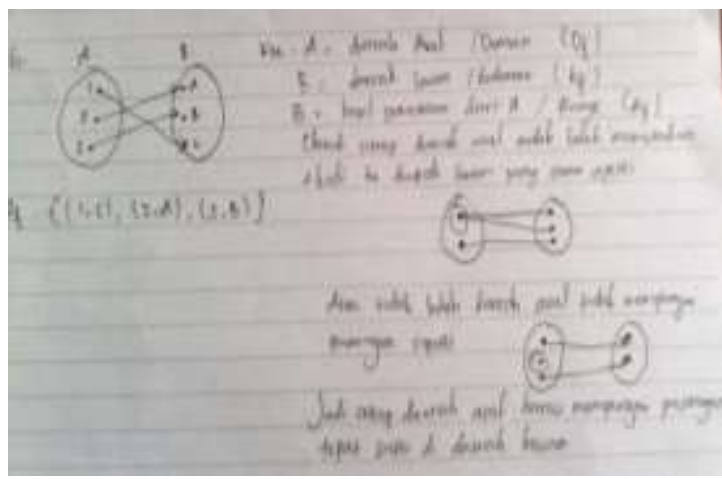

(a)

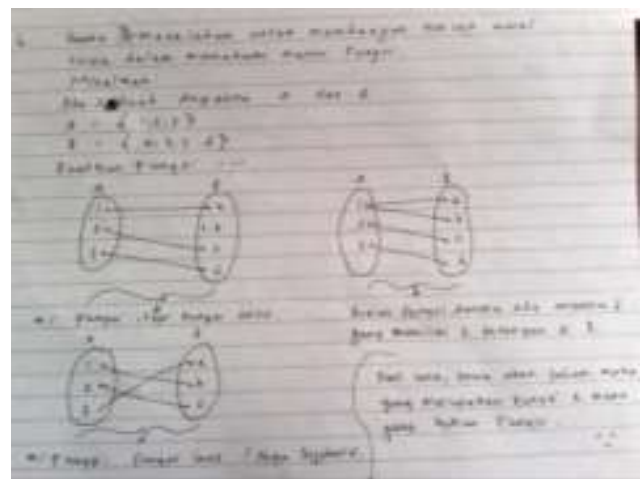

(b)

Figure 1. Student Answer in Case 1

\section{Case 2}

Given the following question: "Make a mathematical problem from this statement: The form of the quadratic function equation is $f(x)=-x^{2}+6 x-5$ so the peak point is (3.4)". From this problem, students are expected to be able to make mathematical 
problems that essentially look for the peak point of the quadratic function $f(x)=-x^{2}+$ $6 \mathrm{x}-5$. To answer these questions, some students give problems correctly as follows:

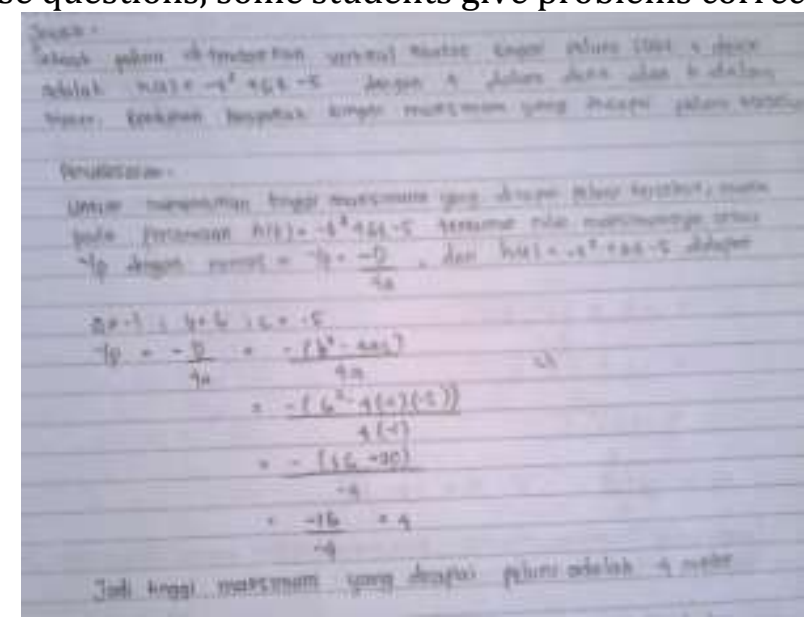

Figure 2. Student Answer in Case 2

However, most students give answers by asking: "Determine the cusp of the quadratic function $f(x)=-x^{2}+6 x-5$ ?". Besides, they also provide the correct solution by answering that the peak point of the function is (3.4).

\section{Case 3}

Given the following question: "How to develop the thinking ability of middle school students to draw a graph of quadratic functions $f(x)=x^{2}-6 x+10$ by utilizing the quadratic function $\mathrm{f}(\mathrm{x})=\mathrm{x}^{2}$. It is expected that students can answer by starting to draw a quadratic function $f(x)=x^{2}$ then changing the form $f(x)=x^{2}-6 x+10$ to $(x)=(x-3)^{2}+1$. Then to draw a graph $f(x)=x^{2}-6 x+10$ using the graph function $\mathrm{f}(\mathrm{x})=\mathrm{x}^{2}$ by sliding to the edge and up. The students' answers to the question were dominated by using the factoring concept without using the function $f(x)=x^{2}$.

Mathematics teaching requires the management of complex learning resources, including subject matter and PCK teachers of mathematics subjects themselves. Effective teaching involves the teacher's interaction with students in understanding the background and experience of students in learning mathematics. Teachers need to form opportunities that allow students to learn meaningfully. In this case, learning involves students' experience in independent learning and places the teacher as a facilitator. Teacher PCK positively predicts student achievement, whose effects are mediated by cognitive activity (Gess-Newsome, Taylor, \& Carlson, 2016).

\section{Correlation of Pedagogical Content Knowledge and Content Knowledge}

The results indicate that CK and PCK of students as prospective teachers still look less. Future math teachers need to have strong CK and PCK in their learning in college (Leong, Chew, Suzieleez Syrene, 2015). Teachers must have the knowledge and motivation to encourage the growth and learning of their students optimally. Therefore, it is important to lecture mathematics teacher candidates to systematically develop PCK and 
mathematical content knowledge as prospective mathematics teachers to improve the quality of education to create meaningful learning situations.

There is a significant correlation between PCK and CK students. It shows that both need to be owned by a teacher in carrying out mathematics learning. A teacher needs to have CK as an introduction in mastering the material to be explained to students. A teacher's CK is a significant predictor for understanding the learning situation (Dunekacke, Jenßen, Blömeke, 2015). To illustrate the material, a prospective teacher needs to have PCK to understand the material being taught. PCK and CK significantly correlate with student achievement in learning (Patricia F. Campbell \& Toni, 2014).

\section{Discussion of Pedagogical Content Knowledge and Content Knowledge}

In case 1, it was seen that students had CK but were still lacking in PCK. Students still use examples and non-examples in explaining mathematics material. Likewise, in case 2, students use direct instructions using the "determine" question. It indicated that teachers still dominated mathematics learning and still highlighted the lowest cognitive abilities of students, namely understanding. The view of mental representation in mathematics education is proven by learning theories that characterize how the teacher modifies the learning to be carried out by students. Learning must be able to construct students' thoughts and experiences in learning mathematics. Teachers need to treat mathematics as an individual, constructive and social practice (Cobb, Yackel, \& Wood, 1992). This form of individual and constructive activity in mathematics learning can be done by presenting mathematical problems at the beginning of learning so that students can construct their knowledge by placing the teacher as a facilitator. Social practice as a form of cooperation between students provides benefits to exchange ideas about the solution of a given mathematical problem. In this case, students' mathematical beliefs in learning mathematics need serious attention.

In case 3 , the student did not pay attention to the instruction questions to use $f(x)=x^{2}$ in giving an explanation to draw the function $f(x)=x^{2}-6 x+10$. It is suspected that students have not understood the quadratic function content for junior high school level. The finding of this case is that a teacher's PCK needs to be accompanied by knowledge of mathematical content. PCK and content knowledge are two different dimensions, but both are correlated (Kleickmann, Richter, \& Kunter, 2015). In contrast to cases 1 and 2, students' mathematical content knowledge is better than PCK. Indeed, this often happens because mathematical content knowledge is sometimes the center of attention in teaching mathematics. The same thing was expressed by Depaepe et al. (2015) that knowledge of teacher content is better than that of PCK. A teacher who has good knowledge of mathematical content is the main capital in teaching mathematics. Next, just how the teacher conveyed the mathematical knowledge so that students could understand it and make learning fun. Knowledge content and PCK are directly and positively related to students' mathematics achievement (Patricia F. Campbell \& Toni, 2014). 
Lecturers have the core responsibility to improve students' content knowledge and PCK as prospective teachers and develop their confidence in mathematics learning. PCK is a form of interaction between conceptual mathematical understanding, teaching experience, and class interaction (Hauk, Toney, \& Jackson, 2014). The three components are the beginning of the formation of the teacher PCK. A teacher who has a mathematical understanding needs to teach to know the conditions of mathematics learning and see various possibilities in interacting with students. There are two internal PCK constructs, namely the application of the understanding topic to class content and variable consideration of students' understanding of the choice of learning practices (GessNewsome, Taylor, \& Carlson, 2016).

Efforts to develop PCK of teacher candidates need to involve them in concretely teaching students to show how competent prospective teachers are when interacting with students. PCK development needs to involve instructional classrooms such as videos, tapes, or student activities (McNeill, González-Howard, Katsh-Singer, \& Loper, 2016). It is intended as a source of observation in observing teacher activities to conduct further evaluations in the development of PCK. It is expected to improve teacher quality which has implications for increasing the quality of student learning. Changes in the behavior of PCK prospective teachers produce better students' learning (Sinelnikov, Kim, \& Ward, 2016). It is supported by research Gess-Newsome, Taylor, \& Carlson (2019) that a prospective teacher's CK and PCK affect students' achievements.

\section{CONCLUSION}

This study found the importance of beliefs to develop prospective teachers' PCK and CK. It is necessary to explore the extent of understanding of constructivism and its implications in the practice of teaching in junior high schools about the material of quadratic functions. This study reveals the challenge for prospective teachers to organize learning from a constructivist perspective as an effort in professional development.

Students will succeed in solving mathematical problems if they present mathematical problems that reflect their level of understanding. Prospective teachers who choose appropriate mathematical problems will increase students' understanding of mathematics and increase their interest. In guiding students in mathematics learning, prospective teachers need to know to solve mathematical problems differently and efficiently.

\section{REFERENCES}

An, S., Kulm, G., \& Wu, Z. (2004). The Pedagogical Content Knowledge of Middle School, Mathematics Teachers in China and the U.S. Journal of Mathematics Teacher Education, https://doi.org/10.1023/b:jmte.0000021943.35739.1c.

145-172.

Ball, D.L., Thames, M.H., \&Phelps, G. (2016). Content Knowledge for Teaching. Journal of Teacher

Education, http://kprcontentlibrary.kprdsb.ca:8080/docushare/dsweb/Get/Document- 
9589/content_knowledge_for_teaching_what_makes_it_special.pdf.

Ball, D. L., Thames, M. H., Phelps, G., Loewenberg Ball, D., Thames, M. H., \& Phelps, G. (2008). Content Knowledge for Teaching: What Makes It Special? Journal of Teacher Education, 59(5), 389-407. https://doi.org/10.1177/0022487108324554.

Cobb, P., Yackel, E., \& Wood, T. (1992). A constructivist alternative to the representational view of mind in mathematics education. Journal for Research in Mathematics Education, 23(1), 2-33. https://doi.org/10.2307/749161.

Depaepe, F., Verschaffel, L., \& Kelchtermans, G. (2013). Pedagogical content knowledge: A systematic review of the way in which the concept has pervaded mathematics educational research. Teaching and Teacher Education, 34, 12-25. http://210.240.194.115/ntcudct_courses/digitalcommunication/10323/ftp_writ e/0_personal_case/00_\%E5\%8F\%83\%E8\%80\%83/BIT102101_\%E6\%9B\%BE\% E5\%A9\%89\%E8\%8F\%B1/\%E8\%8B\%B1\%E6\%96\%87\%E8\%AB\%96\%E6\%96 \%87/2013_Pedagogical\%20content $\% 20$ knowledge $\% 20 \mathrm{~A} \% 20$ systematic\%20rev iew $\% 20$ of $\% 20$ the $\% 20$ way\%20in\%20which $\% 20$ the $\% 20$ concept $\% 20$ has $\% 20$ per vaded\%20mathematics\%20educational\%20research.pdf.

Depaepe, F., Torbeyns, J., Vermeersch, N., Janssens, D., Janssen, R., Kelchtermans, G., Verschaffel, L., \& Van Dooren, W. (2015). Teachers' content and pedagogical content knowledge on rational numbers: A comparison of prospective elementary and lower secondary school teachers. Teaching and Teacher Education, 47, 82-92. https://doi.org/10.1016/j.tate.2014.12.009.

Dunekacke, S., Jenßen, L., \& Blömeke, S. (2015). Effects of Mathematics Content Knowledge on Pre-school Teachers' Performance: a Video-Based Assessment of Perception and Planning Abilities in Informal Learning Situations. International Journal of Science and Mathematics Education, 13(2), 267-286. https://doi.org/10.1007/s10763-014-9596-z.

Even, R. (1993). Subject-Matter Knowledge and Pedagogical Content Knowledge: Prospective Secondary Teachers and the Function Concept. Journal for Research in Mathematics Education, 24(2), 94-116. https://doi.org/10.2307/749215.

Gess-Newsome, J., Taylor, J. A., Carlson, J., Gardner, A. L., Wilson, C. D., \& Stuhlsatz, M. A. M. (2016). Teacher pedagogical content knowledge, practice, and student achievement†. International Journal of Science Education, $0(0), 1-20$. https://doi.org/10.1080/09500693.2016.1265158.

Gess-Newsome, J., Taylor, J. A., Carlson, J., Gardner, A. L., Wilson, C. D., \& Stuhlsatz, M. A. M. (2019). Teacher pedagogical content knowledge, practice, and student achievement $\dagger$. International Journal of Science Education, 41(7), 944-963. https://doi.org/10.1080/09500693.2016.1265158.

Hauk, S., Toney, A., Jackson, B., Nair, R., \& Tsay, J.-J. (2014). Developing a model of pedagogical content knowledge for secondary and post-secondary mathematics instruction. Dialogic Pedagogy: An International Online Journal, 2(2014), 16-40. https://doi.org/10.5195/DPJ.2014.40.

Kleickmann, T., Richter, D., Kunter, M., Elsner, J., Besser, M., Krauss, S., Cheo, M., \& Baumert, J. (2015). Content knowledge and pedagogical content knowledge in Taiwanese and German mathematics teachers. Teaching and Teacher Education, 46, 115-126. https://doi.org/10.1016/j.tate.2014.11.004. 
Kwong, C. W., Kai, Y., Joseph, K., Chun, C., Eric, M., \& Khoh, L. S. (2007). Development of Mathematics Pedagogical Content Knowledge in Student Teachers. The Mathematics Educator, 10(2), 27-54. http://hdl.handle.net/10497/102.

Leong, K. E., Chew, C. M., \& Suzieleez Syrene, A. R. (2015). Understanding Malaysian PreService Teachers Mathematical Content Knowledge and Pedagogical Content Knowledge. Eurasia Journal of Mathematics, Science and Technology Education, 11(3), 363-370. https://doi.org/10.12973/eurasia.2015.1346a.

Margiyono, I., \& Mampouw, H. L. (2011). Deskripsi Pedagogical Content Knowledge Guru Pada Bahasan Tentang Bilangan Rasional. Yogyakarta.

McCray, J. S., \& Chen, J.-Q. (2012). Pedagogical Content Knowledge for Preschool Mathematics: Construct Validity of a New Teacher Interview. Journal of Research in Childhood Education, 26(3), 291-307. https://doi.org/10.1080/02568543.2012.685123.

McNeill, K. L., González-Howard, M., Katsh-Singer, R., \& Loper, S. (2016). Pedagogical content knowledge of argumentation: Using classroom contexts to assess highquality PCK rather than pseudoargumentation. Journal of Research in Science Teaching, 53(2), 261-290. https://doi.org/10.1002/tea.21252.

Niess, M. L. Ã. (2005). Preparing teachers to teach science and mathematics with technology : Developing a technology pedagogical content knowledge. Teaching and Teacher Education, 21, 509-523. https://doi.org/10.1016/j.tate.2005.03.006.

Patricia F. Campbell, Masako Nishio, Toni M. Smith, Lawrence M. Clark, Darcy L. Conant, Amber H. Rust, Jill Neumayer DePiper, Toya Jones Frank, Matthew J. Griffin, \& Youyoung Choi. (2014). The Relationship Between Teachers' Mathematical Content and Pedagogical Knowledge, Teachers' Perceptions, and Student Achievement. Journal for Research in Mathematics Education, 45(4), 419. https://doi.org/10.5951/jresematheduc.45.4.0419.

Shulman, L. S. (1986). Knowledge and Teaching: Foundations of The New Reform. Harvard Educational Review, 57. https://meridian.allenpress.com/her/articleabstract/57/1/1/31319/Knowledge-and-Teaching-Foundations-of-theNew?redirectedFrom=fulltext.

Şimşek, N., \& Boz, N. (2016). Analysis of Pedagogical Content Knowledge Studies in the Context of Mathematics Education in Turkey: A Meta-Synthesis Study. Kuram ve Uygulamada Egitim Bilimleri Educational Science: Teory\&Practice, 16(3), 799826. https://doi.org/10.12738/estp.2016.3.0382.

Sinelnikov, O. A., Kim, I., Ward, P., Curtner-Smith, M., \& Li, W. (2016). Changing beginning teachers' content knowledge and its effects on student learning. Physical Education and Sport Pedagogy, 21(4), 425-440. https://doi.org/10.1080/17408989.2015.1043255. 